\title{
RANCANG BANGUN IPAL (INSTALASI PENGOLAHAN AIR LIMBAH) PORTABLE UNTUK SKALA IKM DENGAN MENGGUNAKAN METODE TAGUCHI
}

\author{
${ }^{1}$ Silvia Uslianti, ${ }^{2}$ Ivan Sujana, ${ }^{3}$ Tri Wahyudi, ${ }^{4}$ Riadi Budiman \\ ${ }_{1,2,3,4}$ Program Studi Teknik Industri Fakultas Teknik Universitas Tanjungpura \\ Jl. Prof.Dr.H.Hadari Nawawi / Jendral Ahmad Yani, Pontianak - Kalimantan Barat \\ e-mail: ratihrahma2012@gmail.com
}

\begin{abstract}
Based on regulations Regional City of Pontianak No. 2 of 2013 it is stated that the Installation of Wastewater Treatment (IPAL) is included in the plan long-term Pontianak city layout. This indicates good industry large and small must have an IPAL that is in accordance with the quality standards that have been set. However, based on data from the Environment Agency (BLH) 2017, the level management of IKM IPAL is still below 50\% of the total existing IKM. This matter because of the cost of procuring a high WWTP. The aim of this study to design an IPAL that is portable and can be reached by small industry using the Taguchi experimental method. The steps of his research began with the design of the WWTP body, then the Taguchi experiment to determine the media filter (Zeolite: Active Charcoal), Dacron Thickness, palm fiber thickness and number of plates (Current strength of 10 A). Taguchi experiments are carried out using orthogonal array L9 (34). Based on the Taguchi experiment, the characteristics were carried out the intended quality is smaller the better the results of the combination of zeolite and activated charcoal are obtained as much as 70:30 with 4 plates. This proves that the combination optimal these factors can increase the optimization of the work of IPALP portable.
\end{abstract}

Key words : Taguci Experiment; Installation of Wastewater Treatment (IPAL); Wastewater Treatment; Building Design

\begin{abstract}
Abstrak
Berdasarkan Peraturan Daerah Kota Pontianak No 2 Tahun 2013 disebutkan bahwa Intalasi Pengolahan Air Limbah (IPAL) termasuk dalam rencana tata ruang kota Pontianak jangka panjang. Hal ini mengindikasi baik industri besar maupun kecil wajib memiliki IPAL yang sesuai dengan baku mutu yang telah ditetapkan. Namun, berdasarkan data Badan Lingkungan Hidup (BLH) 2017, tingkat pengelolaan IPAL IKM masih dibawah 50\% dari total IKM yang ada. Hal ini dikarenakan biaya dalam pengadaan IPAL yang tinggi. Penelitian ini bertujuan untuk merancang bangun IPAL yang bersifat portable dan dapat dijangkau oleh industri kecil dengan menggunakan metode eksperimen taguchi. Langkah-langkah penelitiannya dimulai dengan rancang body IPAL, kemudian eksperimen taguchi untuk menentukan media filter (Zeolit:Arang Aktif), Ketebalan Dacron, ketebalan ijuk dan jumlah plat (Kuat arus 10 A). Eksperimen taguchi dilakukan menggunakan orthogonal array $L_{9}\left(3^{4}\right)$. Berdasarkan eksperimen taguchi yang dilakukan menggunakan karakteristik kualitas yang dituju yakni smaller the better diperoleh hasil kombinasi perbandingan zeolit dan arang aktif sebesar 70:30 dengan jumlah plat sebanyak 4 plat. Hal ini membuktikan bahwa kombinasi optimal faktor-faktor tersebut dapat meningkatkan optimalisasi dari kerja IPAL portable.
\end{abstract}

Kata kunci : Eksperimen Taguchi, IPAL, Pengolahan Air Limbah, Rancang Bangun

\section{PENDAHULUAN}

Kota Pontianak berkomitmen dalam penanganan limbah cair yang berasal dari industri baik industri besar maupun industri kecil. Hal ini sesuai dengan kebijakan yang dikeluarkan oleh Pemerintah Daerah Kota Pontianak melalui Peraturan Daerah Kota Pontianak No 2 Tahun 2013 tentang rencana tata ruang wilayah kota Pontianak tahun 2013-2033. Dalam peraturan daerah ini disebutkan bahwa IPAL termasuk dalam rencana tata ruang kota Pontianak jangka panjang. Peraturan daerah ini diperkuat juga oleh Peraturan Daerah Kota Pontianak Nomor 5 Tahun 2013 tentang pengendalian pencemaran air. Dalam hal ini pemerintah kota mengatur dan mengendalikan pembuangan air limbah termasuk menentukan baku mutu limbah cair. Indikasinya adalah baik industri besar maupun industri kecil wajib memiliki IPAL yang sesuai dengan baku mutu yang telah ditetapkan. Namun, berdasarkan data Badan Lingkungan Hidup (BLH) kota Pontianak menyatakan partisipasi IKM dalam melaporkan IPAL per tiga bulan 
masih rendah. Pengelolaan IPAL IKM masih dibawah 50\% .Hal ini dikarenakan biaya dalam pengadaan dan pelaporan IPAL masih tinggi (Tribun Pontianak, 2017). Kajian terkait rancang bangun IPAL untuk IKM di kota Pontianak perlu mendapat perhatian khusus.

Berbagai kajian terkait penanganan limbah IKM terutama limbah cair telah banyak dilakukan Fukushima \& Tan (2014) meneliti tentang penanganan limbah cair dari industri tahu di Taiwan dengan menggunakan pendekatan biologi dengan tujuan meminimasi chemical oxygen demand (COD) dan minimasi investasi ekonomi. Ioannou-Ttofa et al.(2017) tentang penanganan limbah penggilingan buah zaitun dengan menggunakan oksidasi biologi, filtrasi membrane dan proses separasi. Aikenhead et al.(2015) yang mengkaji penanganan limbah pada pabrik susu. Penelitian-penelitian tersebut menggunakan pendekatan biologi dan kimia serta menekankan pada biaya yang rendah. Pengendalian pencemaran limbah cair yang berasal dari IKM tidak mungkin dapat dilakukan dengan pendekatan yang sama seperti industri skala besar (Sulaksono et al, 2015).

Salah satu metode pengolahan limbah industri dengan efisiensi biaya yang murah dan efektif adalah dengan menggunakan metode elektrokoagulasi (Reddithota et al, 2007). Elektrokoagulasi merupakan metode elektrokimia untuk pengolahan air dimana pada anoda terjadi pelepasan koagulan aktif berupa ion logam (biasanya aluminium atau besi) ke dalam larutan, sedangkan pada katoda terjadi reaksi eletrolisis berupa pelepasan gas hydrogen (Holt et al., 2005). Berbagai penelitian tentang penggunaan metode elektrokoagulasi telah banyak dilakukan. Penggunaan metode elektrokoagulasi populer digunakan dalam mengatasi limbah tekstil seperti yang telah diteliti oleh Kobya et al.,(2003), Alinsafi et al.( 2005) dan (Ngatin et $a l$, 2010) pada industri olahan kulit (Siringo et al.,2013) dan industri pengolahan limbah kelapa sawit (Hanum et al., 2015). Penelitian terkait penggunaan metode elektrokoagulasi untuk penanganan limbah cair yang berasal dari IKM makanan akan dapat menjadi kajian yang menarik.

Seperti yang telah dipaparkan sebelumnya, bahwa Pemerintah Kota Pontianak melalui Badan Lingkungan Hidup memberi pengaturan dan pengawasan terhadap kualitas air limbah. Kualitas air limbah maksudnya adalah ukuran batas atau kadar mahluk hidup, zat, energi atau komponen lain yang ada atau harus ada unsur pencemaran yang ditenggang adanya dalam air pada sumber-sumber tertentu sesuai dengan peruntukkannya. Hal ini mengindikasikan bahwa pentingnya kualitas dalam rancang bangun pengolahan limbah cair sehingga keluaran dari IPAL ini nantinya sesuai dengan kualitas limbah yang boleh dibuang. Salah satu metode yang dapat digunakan untuk mengidentifikasi faktor-faktor yang mempengaruhi kualitas pada rancangan produk adalah metode Taguchi. Metode Taguchi dapat digunakan untuk meningkatkan kualitas suatu produk dengan meminimalisir faktor gangguan, sehingga dapat dihasilkan produk yang dapat memenuhi standar kualitas yang diinginkan. Metode Taguchi telah digunakan oleh Aber et al.,(2010) untuk mendapatkan kondisi optimum jenis dan dosis koagulan dari penangan limbah industri penyamakan kulit. Metode Taguchi dalam penelitian ini digunakan sebagai penentu faktor control seperti media filter (zeolite dan arang aktif), ketebalan Dacron, ketebalan ijuk dan jumlah plat.

Berbagai analisa dan pertimbangan digunakan dalam penelitian ini dengan harapan dapat menghasilkan rancang bangun IPAL yang dapat digunakan oleh IKM di Pontianak.selain itu rancangan bangun IPAL akan dibuat Portable sehingga pengguna tidak hanya berbasis IKM rumah tangga tapi juga dapat menjangkau rumah makan terutama rumah makan berkonsep food street. 


\section{METODE PENELITIAN}

\section{Pengumpulan Data Awal}

Pengumpulan data awal sebelum eksperimen dilakukan dengan melakukan pengukuran sampel limbah pada IKM rumah makan yang ada di kota Pontianak. Terdapat 24 limbah yang diambil dari IKM dan rumah makan yang diukur baku mutu limbahnya meliputi kandungan BOD, TSS serta minyak dan lemak. Selain itu dilakukan identifikasi faktor-faktor dominan yang berpengaruh terhadap limbah dilakukan melalui observasi dan wawancara dengan pemilik usaha. Hasil observasi, wawancara dan pengumpulan data awal digunakan untuk menentukan faktor kontrol yang diduga berpengaruh terhadap kualitas limbah IKM.

\section{Rancang Bangun IPAL Portable}

Rancang bangun IPAL Portable akan menggunakan metode elektrokoagulasi. Gambar 1 berikut ini merupakan diagram alir dalam rancang bangun IPAL Portable.

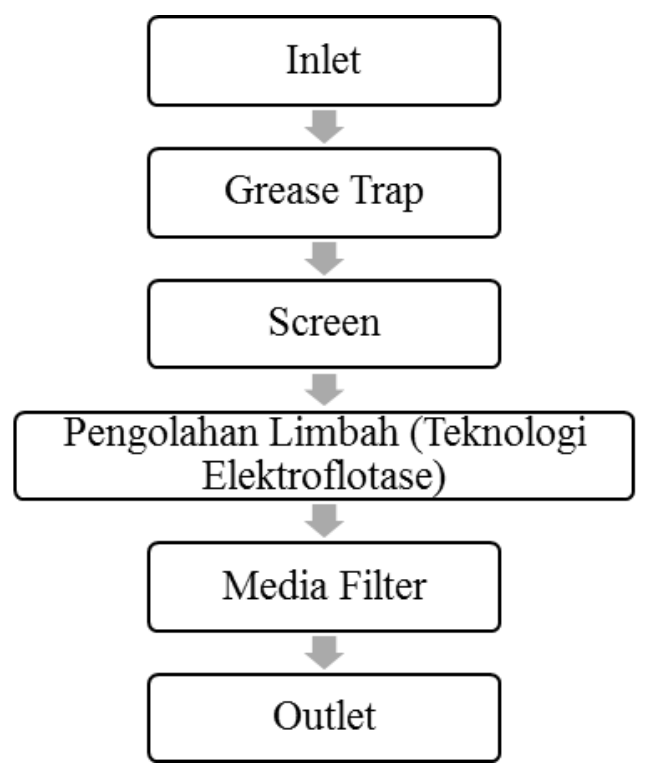

Gambar 1. Flow diagram unit IPAL portable

Tahapan rancang bangun Unit IPAL terdiri dari beberapa bagian yakni:

a. Inlet, saluran masuk limbah cair

b. Grease Trap, perangkap untuk lemak/minyak.

c. Screen, saringan.

d. Teknologi Elektroflotase, reaktor proses reaksi oksidasi dan reduksi

e. Media Filter, terdiri dari zeolit, arang aktif, dacron, dan ijuk.

f. Outlet, saluran keluar limbah cair hasil pengolahan.

\section{Eksperimen Taguchi}

Eksperimen Taguchi dilakukan dengan pengolahan data awal yaitu perhitungan rata-rata, standar deviasi dan range data. Pengolahan ini bertujuan untuk mengetahui gambaran kondisi awal limbah yang berasal dari IKM. Sebelum dilakukan eksperimen Taguchi dilakukan penentuan jumlah level dan nilai level faktor. Tabel 1 berikut merupakan penentuan faktor, jumlah level dan nilai level faktor yang digunakan dalam eksperimen taguchi. 
Tabel 1. Faktor dan level eksperimen taguchi

\begin{tabular}{lcccc}
\hline & Faktor & $\mathbf{1}$ & Level & $\mathbf{2}$ \\
\hline 1 & Media Filter & $50: 50$ & $30: 70$ & $70: 30$ \\
& (Zeolit:Arang Aktif) & $3 \mathrm{~cm}$ & $5 \mathrm{~cm}$ & $7 \mathrm{~cm}$ \\
2 & Ketebalan Dacron & $3 \mathrm{~cm}$ & $5 \mathrm{~cm}$ & $7 \mathrm{~cm}$ \\
3 & Ketebalan Ijuk & 2 & 4 & 6 \\
4 & Jumlah Plat (Kuat Arus & 2 & & \\
& 10A) & & &
\end{tabular}

Setelah itu dilakukan eksperimen taguchi menggunakan orthogonal array $\mathrm{L}_{9}\left(3^{4}\right)$ yang artinya eksperimen dilakukan 9 kali dengan jumlah faktor 4 dan level 3. Replikasinya dilakukan sebanyak 4 kali. Tabel 2 berikut merupakan matriks orthogonal $\mathrm{L}_{9}\left(3^{4}\right)$ yang menjadi dasar eksperimen taguchi.

Tabel 2. Matriks orthogonal array $\mathrm{L}_{9}\left(3^{4}\right)$

\begin{tabular}{ccccc}
\hline \multirow{2}{*}{ Eksperimen } & \multicolumn{4}{c}{ Faktor } \\
\cline { 2 - 5 } & $\mathbf{1}$ & $\mathbf{2}$ & $\mathbf{3}$ & $\mathbf{4}$ \\
\hline 1 & 1 & 1 & 1 & 1 \\
2 & 1 & 2 & 2 & 2 \\
3 & 1 & 3 & 3 & 3 \\
4 & 2 & 1 & 2 & 3 \\
5 & 2 & 2 & 3 & 1 \\
6 & 2 & 3 & 1 & 2 \\
7 & 3 & 1 & 3 & 2 \\
8 & 3 & 2 & 1 & 3 \\
9 & 3 & 3 & 2 & 1 \\
\hline
\end{tabular}

\section{Pengolahan Data dan Analisis}

Pengolahan data eksperimen taguchi dilakukan dalam beberapa tahap. Tahap awal dilakukan dengan menghitung rata-rata nilai limbah, standar deviasi, rasio $\mathrm{S} / \mathrm{N}$ data awal dan ANOVA. Berikut langkah langkah dalam pengolahan data eksperimen Taguchi

\section{Rasio S/N}

Rasio S/N (Signal to Noise) digunakan untuk mengetahui level faktor mana yang berpengaruh pada hasil eksperimen. Karakteristik Rasio S/N yang dipakai adalah smaller the better. Model matematisnya adalah sebagai berikut:

Rasio $\frac{S}{N}=-10 x \log \left(\frac{1}{n} \sum y^{2}\right)$

\section{ANOVA}

Analisis varians dua arah digunakan untuk data eksperimen yang memiliki dua faktor atau lebih dan dua level atau lebih. Tabel analisis terdiri dari perhitungan derajat kebebasan, jumlah kuadrat, rata-rata jumlah kuadrat dan F-rasio. Pada perhitungan ANOVA dihitung dua yakni ANOVA data awal dan ANOVA rasio S/N

\section{Uji Hipotesis}

Uji Hipotesis F dilakukan dengan cara membandingkan variansi yang disebabkan masingmasing faktor dan variansi error. Variansi error adalah variansi setiap individu dalam pengamatan yang timbul karena faktor yang tidak dapat dikendalikan.

Hipotesis pengujian dalam suatu percobaan adalah: 
$\mathrm{H}_{0}=$ tidak ada pengaruh faktor terhadap kualitas air limbah (BODs, TSS serta Minyak dan Lemak)

$\mathrm{H}_{1}=$ ada pengaruh faktor terhadap kualitas air limbah limbah (BODs, TSS serta Minyak dan Lemak).

Apabila uji $\mathrm{F}_{\text {hitung }}<\mathrm{F}_{\text {(Tabel) }}$ maka $\mathrm{H}_{1}$ diterima, artinya ada pengaruh faktor terhadap kualitas air limbah.

\section{Pooling up faktor}

Pooling up dirancang untuk mengestimasi variansi error pada analisis varians. Pooling up akan mengakumulasi beberapa varians error dari beberapa faktor yang kurang berpengaruh bagi kualitas air limbah.

\section{Persen kontribusi}

Untuk mengetahui seberapa besar kontribusi yang diberikan oleh masing-masingfaktor dan interaksi, terlebih dahulu dihitung SS'

$$
S S_{\text {faktor }}^{\prime}=S S_{\text {faktor }}-M S_{\text {errc }}
$$

Persen kontribusi masing-masing faktor dihitung dengan rumus:

$\mu=\frac{S S_{\text {faktor }}}{S S_{T}} \times 100 \%$

\section{Prediksi dan rasio S/N kondisi optimum}

Setelah diketahui faktor-faktor yang berpengaruh secara signifikan, langkah selanjutnya dilakukan perhitungan prediksi rata-rata yang optimal untuk BODs, TSS serta Minyak dan Lemak saat menggunakan IPAL portable ini.

\section{HASIL DAN PEMBAHASAN}

\section{Rancang Bangun IPAL Portable}

Berdasarkan data yang diperoleh, maka didesain IPAL untuk IKM. Rancang bangun alat dipertimbangkan aspek kemudahan dalam pemindahan. Sehingga dapat digunakan oleh IKM rumah makan yang berkonsep food street. Berikut adalah desain IPAL portabel diterangkan pada gambar 3 berikut ini:
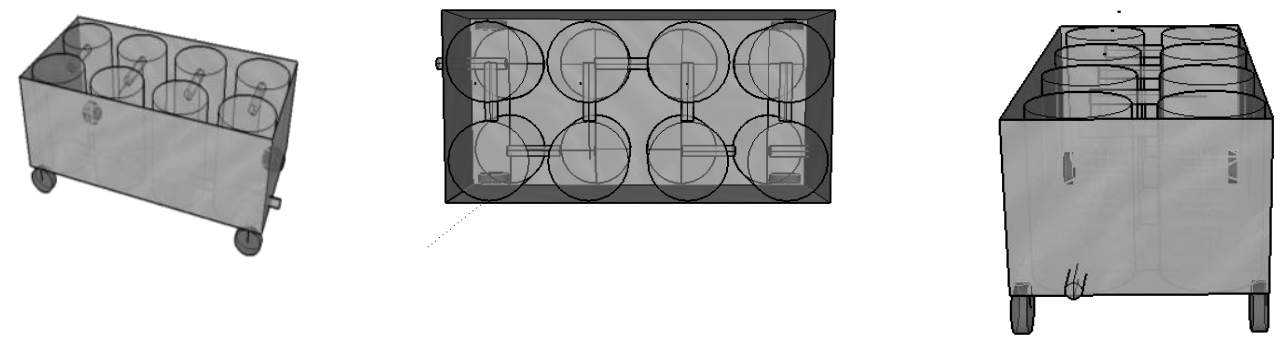

Gambar 3. Desain IPAL portable

Berdasarkan desain IPAL Portable pada gambar 3, maka dibuat IPAL Portable berdasarkan metode elektrokoagulasi yang ditunjukkan pada gambar 4 . 

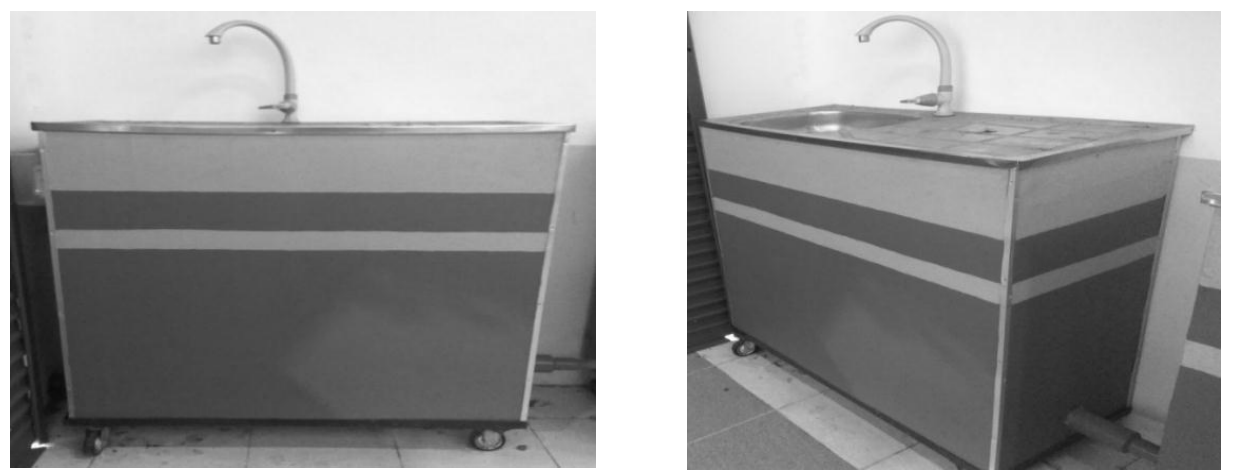

Gambar 4. Body IPAL

\section{Hasil Eksperimen Taguchi}

Data Eksperimen dan Perhitungan Mean

Dari eksperimen taguchi yang telah dilakukan untuk BODs, TSS serta Minyak dan Lemak, maka didapatkan data eksperimen yang dapat dilihat pada tabel 3, 4 dan 5 berikut ini.

Tabel 3. Hasil eksperimen dan perhitungan mean BODs eksperimen taguchi

\begin{tabular}{ccccccccccc}
\hline \multirow{2}{*}{ Eksperimen } & \multicolumn{9}{c}{ Faktor } & \multicolumn{8}{c}{ Replikasi BODs } & & \\
\cline { 2 - 9 } & $\mathbf{1}(\mathbf{A})$ & $\mathbf{2 ( B )}$ & $\mathbf{3 ( C )}$ & $\mathbf{4 ( D )}$ & $\mathbf{R 1}$ & $\mathbf{R 2}$ & $\mathbf{R 3}$ & $\mathbf{R 4}$ & Jumlah & Mean \\
\hline 1 & 1 & 1 & 1 & 1 & 22,37 & 22,47 & 22,51 & 24,26 & 91,60 & 22,90 \\
2 & 1 & 2 & 2 & 2 & 23,73 & 24,23 & 24,32 & 24,81 & 97,09 & 24,27 \\
3 & 1 & 3 & 3 & 3 & 18,31 & 18,46 & 18,54 & 19,39 & 74,69 & 18,67 \\
4 & 2 & 1 & 2 & 3 & 25,08 & 25,24 & 25,65 & 27,16 & 103,13 & 25,78 \\
5 & 2 & 2 & 3 & 1 & 25,76 & 26,70 & 26,02 & 27,31 & 105,80 & 26,45 \\
6 & 2 & 3 & 1 & 2 & 25,08 & 25,95 & 25,70 & 26,29 & 103,03 & 25,76 \\
7 & 3 & 1 & 3 & 2 & 25,08 & 25,13 & 25,48 & 25,69 & 101,39 & 25,35 \\
8 & 3 & 2 & 1 & 3 & 21,68 & 22,56 & 22,60 & 22,81 & 89,64 & 22,41 \\
9 & 3 & 3 & 2 & 1 & 27,12 & 27,65 & 27,41 & 28,09 & 110,26 & 27,57 \\
Jumlah & & & & & & & & & & 219,16 \\
Rata-rata & & & & & & & & & & 24,35 \\
\hline
\end{tabular}

Tabel 4. Hasil eksperimen dan perhitungan mean TSS eksperimen taguchi

\begin{tabular}{ccccccccccc}
\hline \multirow{2}{*}{ Eksperimen } & \multicolumn{1}{c}{ Faktor } & \multicolumn{1}{c}{ Replikasi TSS } \\
\cline { 2 - 9 } & $\mathbf{1}(\mathbf{A})$ & $\mathbf{2 ( B )}$ & $\mathbf{3 ( C )}$ & $\mathbf{4 ( D )}$ & $\mathbf{R 1}$ & $\mathbf{R 2}$ & $\mathbf{R 3}$ & $\mathbf{R 4}$ & Jumlah & Mean \\
\hline 1 & 1 & 1 & 1 & 1 & 51,73 & 51,86 & 51,82 & 51,99 & 207,40 & 51,85 \\
2 & 1 & 2 & 2 & 2 & 45,6 & 46,19 & 46,1 & 46,78 & 184,67 & 46,17 \\
3 & 1 & 3 & 3 & 3 & 45,2 & 45,44 & 45,35 & 45,68 & 181,67 & 45,42 \\
4 & 2 & 1 & 2 & 3 & 26,93 & 27,5 & 27,09 & 28,07 & 109,59 & 27,40 \\
5 & 2 & 2 & 3 & 1 & 27,47 & 27,72 & 28,41 & 27,98 & 111,58 & 27,90 \\
6 & 2 & 3 & 1 & 2 & 14,19 & 14,81 & 15,06 & 15,42 & 59,48 & 14,87 \\
7 & 3 & 1 & 3 & 2 & 15,6 & 16 & 15,64 & 16,4 & 63,64 & 15,91 \\
8 & 3 & 2 & 1 & 3 & 18,53 & 19,45 & 19,41 & 20,36 & 77,75 & 19,44 \\
9 & 3 & 3 & 2 & 1 & 27,6 & 27,89 & 28,13 & 28,18 & 111,80 & 27,95 \\
Jumlah & & & & & & & & & & 276,90 \\
Rata-rata & & & & & & & & & & 30,77 \\
\hline
\end{tabular}


Tabel 5. Hasil eksperimen dan perhitungan mean minyak dan lemak eksperimen taguchi

\begin{tabular}{|c|c|c|c|c|c|c|c|c|c|c|}
\hline \multirow{2}{*}{ Eksperimen } & \multicolumn{4}{|c|}{ Faktor } & \multicolumn{4}{|c|}{ Replikasi Minyak dan Lemak } & \multirow[b]{2}{*}{ Jumlah } & \multirow[b]{2}{*}{ Mean } \\
\hline & $1(\mathrm{~A})$ & 2(B) & $3(\mathrm{C})$ & 4(D) & R1 & $\mathbf{R 2}$ & R3 & R4 & & \\
\hline 1 & 1 & 1 & 1 & 1 & 1,09 & 1,88 & 2,98 & 1,19 & 7,14 & 1,79 \\
\hline 2 & 1 & 2 & 2 & 2 & 0,31 & 1,08 & 1,4 & 0,82 & 3,61 & 0,90 \\
\hline 3 & 1 & 3 & 3 & 3 & 0,65 & 1,08 & 1,73 & 0,8 & 4,26 & 1,07 \\
\hline 4 & 2 & 1 & 2 & 3 & 1,19 & 2,07 & 3,26 & 1,34 & 7,86 & 1,97 \\
\hline 5 & 2 & 2 & 3 & 1 & 1 & 1,55 & 2,55 & 1,94 & 7,04 & 1,76 \\
\hline 6 & 2 & 3 & 1 & 2 & 0,39 & 1,21 & 1,6 & 1,26 & 4,46 & 1,12 \\
\hline 7 & 3 & 1 & 3 & 2 & 0,44 & 0,61 & 1,05 & 0,49 & 2,59 & 0,65 \\
\hline 8 & 3 & 2 & 1 & 3 & 0,28 & 1,12 & 1,41 & 1,16 & 3,97 & 0,99 \\
\hline 9 & 3 & 3 & 2 & 1 & 0,93 & 0,97 & 1,9 & 1,46 & 5,26 & 1,32 \\
\hline Jumlah & & & & & & & & & & 11,55 \\
\hline Rata-rata & & & & & & & & & & 1,28 \\
\hline
\end{tabular}

ANOVA

Perhitungan ANOVA dilakukan untuk mengetahui pengaruh dari faktor-faktor utama terhadap nilai rata-rata respon hasil pengujian eksperimen. Perhitungan ANOVA terdiri dari perhitungan derajat kebebasan, jumlah kuadrat, rata-rata jumlah kuadrat dan F-rasio. Tabel 6 menunjukkan ANOVA eksperimen taguchi untuk BODs, TSS serta minyak dan lemak.

Tabel 6. ANOVA eksperimen taguchi

\begin{tabular}{cccccccc}
\hline \multirow{2}{*}{$\begin{array}{c}\text { Sumber/ } \\
\text { Faktor }\end{array}$} & \multirow{2}{*}{$\mathbf{V}$} & \multicolumn{2}{c}{ BODs } & \multicolumn{2}{c}{ TSS } & \multicolumn{2}{c}{ Minyak/Lemak } \\
\cline { 3 - 8 } & & SS & MS & SS & MS & SS & MS \\
\hline A & 2 & 27.15556 & 13.57778 & 1315.334 & 657.667 & 0.596876 & 0.298438 \\
B & 2 & 0.693035 & 0.346518 & 8.703068 & 4.351534 & 0.154601 & 0.077301 \\
C & 2 & 10.49447 & 5.247234 & 44.03918 & 22.01959 & 0.084956 & 0.042478 \\
D & 2 & 19.52974 & 9.764869 & 157.5692 & 78.78459 & 0.818026 & 0.409013 \\
SS $_{\text {faktor Total }}$ & & 57,8727 & & 1525,645 & & 1,6545 & \\
Error & 18 & 183.81 & 10.21178 & 4582.16 & 254.5646 & 14.90 & 0.827539 \\
Total & 26 & 241.6848 & & 6107.81 & & 16.55 & \\
\hline
\end{tabular}

\section{Perhitungan Rasio S/N}

Data hasil eksperimen taguchi ditransformasikan ke dalam bentuk rasio $\mathrm{S} / \mathrm{N}$ untuk mencari faktor yang berpengaruh terhadap kualitas air limbah dengan baku mutu BODs, TSS serta kandungan minyak dan lemak. Sama halnya dengan perhitungan mean data eksperimen, Rasio S/N juga dengan menggunakan karakteristik smaller the better. Berikut ini merupakan contoh perhitungan rasio $\mathrm{S} / \mathrm{N}$ untuk BODs dilakukan dengan menggunakan persamaan berikut:

$$
\text { Rasio } \frac{S}{N}=-10 x \log \left(\frac{1}{4} \sum 1.09+1.88+2.98+1.19\right)=3.14
$$

Hasil perhitungan Rasio S/N untuk baku mutu BODs, TSS serta Minyak dan Lemak dapat dilihat dengan tabel 7, 8 dan 9 berikut ini : 
Tabel 7. Perhitungan rasio S/N untuk BODs

\begin{tabular}{cccccc}
\hline \multirow{2}{*}{ Eksperimen } & \multicolumn{5}{c}{ Replikasi BODs } \\
\cline { 2 - 5 } & R1 & R2 & R3 & R4 & S/N \\
\hline 1 & 22,37 & 22,47 & 22,51 & 24,26 & 27,18 \\
2 & 23,73 & 24,23 & 24,32 & 24,81 & 27,70 \\
3 & 18,31 & 18,46 & 18,54 & 19,39 & 25,42 \\
4 & 25,08 & 25,24 & 25,65 & 27,16 & 28,21 \\
5 & 25,76 & 26,70 & 26,02 & 27,31 & 28,44 \\
6 & 25,08 & 25,95 & 25,70 & 26,29 & 28,21 \\
7 & 25,08 & 25,13 & 25,48 & 25,69 & 28,08 \\
8 & 21,68 & 22,56 & 22,60 & 22,81 & 27,00 \\
9 & 27,12 & 27,65 & 27,41 & 28,09 & 28,81 \\
\hline
\end{tabular}

Tabel 8. Perhitungan rasio S/N untuk TSS

\begin{tabular}{cccccc}
\hline \multirow{2}{*}{ Eksperimen } & \multicolumn{5}{c}{ Replikasi BODs } \\
\cline { 2 - 5 } & R1 & \multicolumn{1}{c}{ R2 } & R3 & R4 & S/N \\
\hline 1 & 51,73 & 51,86 & 51,82 & 51,99 & 34,29 \\
2 & 45,60 & 46,19 & 46,10 & 46,78 & 33,29 \\
3 & 45,20 & 45,44 & 45,35 & 45,68 & 33,14 \\
4 & 26,93 & 27,50 & 27,09 & 28,07 & 28,75 \\
5 & 27,47 & 27,72 & 28,41 & 27,98 & 28,91 \\
6 & 14,19 & 14,81 & 15,06 & 15,42 & 23,43 \\
7 & 15,60 & 16,00 & 15,64 & 16,40 & 24,03 \\
8 & 18,53 & 19,45 & 19,41 & 20,36 & 25,76 \\
9 & 27,60 & 27,89 & 28,13 & 28,18 & 28,93 \\
\hline
\end{tabular}

Tabel 9. Perhitungan rasio S/N untuk minyak dan lemak

\begin{tabular}{cccccc}
\hline \multirow{2}{*}{ Eksperimen } & \multicolumn{5}{c}{ Replikasi BODs } \\
\cline { 2 - 4 } & $\mathbf{R 1}$ & $\mathbf{R 2}$ & $\mathbf{R 3}$ & $\mathbf{R 4}$ & S/N \\
\hline 1 & 1,09 & 1,88 & 2,98 & 1,19 & 3,14 \\
2 & 0,31 & 1,08 & 1,40 & 0,82 & $-5,21$ \\
3 & 0,65 & 1,08 & 1,73 & 0,80 & $-1,07$ \\
4 & 1,19 & 2,07 & 3,26 & 1,34 & 4,01 \\
5 & 1,00 & 1,55 & 2,55 & 1,94 & 3,38 \\
6 & 0,39 & 1,21 & 1,60 & 1,26 & $-3,16$ \\
7 & 0,44 & 0,61 & 1,05 & 0,49 & $-5,09$ \\
8 & 0,28 & 1,12 & 1,41 & 1,16 & $-5,68$ \\
9 & 0,93 & 0,97 & 1,90 & 1,46 & 1,30 \\
\hline
\end{tabular}




\section{ANOVA Rasio S/N}

Setelah dilakukan perhitungan Rasio S/N, maka dilakukan perhitungan ANOVA. Berikut merupakan ANOVA untuk rasio S/N pada tabel 10.

Tabel 10. Perhitungan ANOVA untuk rasio S/N

\begin{tabular}{llllllll}
\hline $\begin{array}{l}\text { Sumber/Fakto } \\
\mathbf{r}\end{array}$ & \multirow{2}{*}{} & $\mathbf{B O D}$ & \multicolumn{3}{c}{ TSS } & \multicolumn{2}{c}{ Minyak/Lemak } \\
\cline { 3 - 8 } & & SS & MS & SS & MS & SS & MS \\
\hline $\mathrm{A}$ & 2 & 3.8581 & 1.9291 & 97.28519 & 48.6426 & 31.359 & 15.68 \\
$\mathrm{~B}$ & 2 & 0.1869 & 0.0935 & 1.024707 & 0.51235 & 15.211 & 7.605 \\
$\mathrm{C}$ & 2 & 1.4803 & 0.7402 & 9.605775 & 4.80289 & 5.6173 & 2.809 \\
$\mathrm{D}$ & 2 & 2.87 & 1.435 & 21.92044 & 10.9602 & 75.438 & 37.72 \\
SS faktor Total & & 27611.5 & & 30693.06 & & 921.27 & \\
Error & 18 & 34.65 & & 395.78 & & 762.37 & \\
Total & 26 & 43.043 & & 525.6194 & & 889.99 & \\
\hline
\end{tabular}

Hasil perhitungan ANOVA, akan menjadi masukan untuk Pooling Up Faktor Rata-Rata Rasio S/N. Penggabungan faktor sebagai error dimulai dari faktor yang memiliki sum of square (SS) terkecil digabungkan ke dalam pooled error kemudian diuji-F terhadap pooled error tersebut. Banyaknya faktor yang akan di pool yaitu setengah dari jumlah faktor utama, sehingga pada penentuan faktor yang paling berpengaruh terhadap kualitas limbah ini hanya memerlukan 3 atau 4 faktor utama untuk di pooling.

Kualitas baku mutu limbah BODs, TSS dan kandungan minyak lemak setelah dilakukan pooling up faktor. Faktor yang paling berpengaruh adalah Faktor A (media filter zeolite: arang aktif) dan Faktor D (jumlah plat) terhadap kualitas baku limbah. Faktor-faktor ini akan menjadi masukan dalam proses rancang bangun media filtrasi pengolahan air limbah.

Berdasarkan Eksperimen Taguchi dan melalui proses pooling up faktor yang dilakukan dengan menggunakan karakteristik kualitas yang dituju, yaitu smaller the better diperoleh hasil kombinasi media filter yang paling optimal untuk BOD yaitu perbandingan zeolite dan arang aktif sebesar 50:50 dengan jumlah plat sebanyak 6 plat; untuk TSS perbandingan zeolite dan arang aktif sebesar 70:30 dengan jumlah plat sebanyak 4 plat; dan untuk Minyak/Lemak yaitu perbandingan zeolite dan arang aktif sebesar 70:30 dengan jumlah plat sebanyak 4 plat.

\section{Penentuan Nilai Prediksi Baku Mutu Limbah}

Setelah diketahui faktor-faktor yang berpengaruh terhadap kualitas baku mutu limbah melalui pooling up faktor. Maka dilakukan perhitungan prediksi rata-rata optimal untuk BODs, TSS dan Minyak Lemak. Berikut perhitungan manual untuk $\mu$ prediksi BODs

$$
\begin{aligned}
\mu \text { prediksi } & =\overline{\mathrm{Y}}+\left(\overline{A_{1}}-\bar{Y}\right)+\left(\overline{D_{3}}-\bar{Y}\right) \\
& =24,35+(21,95-24,35)+(22,29-24,35) \\
& =19,89
\end{aligned}
$$

Hasil rekapitulasi $\mu$ prediksi untuk nilai mean hasil eksperimen dan Rasio S/N dapat dilihat pada tabel 11 berikut ini :

Tabel 11. $\boldsymbol{\mu}_{\text {prediksi }}$ untuk nilai mean dan $\mathrm{S} / \mathrm{N}$

\begin{tabular}{lll}
\hline $\boldsymbol{\mu}_{\text {prediksi }}$ & Mean & S/N \\
\hline BODs & 19,89 & 25.97 \\
TSS & 15.98 & 24.21 \\
Minyak Lemak & 0.59 & -6.71 \\
\hline
\end{tabular}




\section{SIMPULAN}

Faktor- faktor utama yang berpengaruh secara signifikan terhadap kualitas air limbah IKM dan rumah makan antara lain BODs, TSS serta kandungan Minyak dan Lemak. Berdasarkan eksperimen Taguchi dengan menggunakan karakteristik kualitas yang dituju, yaitu smaller the better diperoleh hasil kombinasi media filter yang paling optimal untuk BODs yaitu perbandingan zeolite dan arang aktif sebesar 50:50 dengan jumlah plat sebanyak 6 plat; untuk TSS perbandingan zeolite dan arang aktif sebesar 70:30 dengan jumlah plat sebanyak 4 plat; dan untuk Minyak/Lemak yaitu perbandingan zeolite dan arang aktif sebesar 70:30 dengan jumlah plat sebanyak 4 plat. Sehingga dapat disimpulkan kondisi optimal terpilih untuk rancang bangun IPAL portable yakni perbandingan zeolit dan arang aktif sebesar 70:30 dengan jumlah plat sebanyak 4.

Saran untuk penelitian selanjutnya adalah perlu ditambahnya faktor dan level untuk melakukan eksperimen taguchi untuk meningkatkan kualitas mutu dari IPAL. Selain itu rancang bangun IPAL kedepannya dapat dikaji lagi kapasitasnya untuk skala industri yang lebih besar sehingga tidak hanya untuk skala IKM saja.

\section{DAFTAR PUSTAKA}

Aber, S., Salari, D., \& Parsa, M. R. (2010). Employing the Taguchi method to obtain the optimum conditions of coagulation-flocculation process in tannery wastewater treatment. Chemical Engineering Journal, 162(1), 127-134. https://doi.org/10.1016/j.cej.2010.05.012

Aikenhead, G., Farahbakhsh, K., Halbe, J., \& Adamowski, J. (2015). Application of process mapping and causal loop diagramming to enhance engagement in pollution prevention in small to medium size enterprises: Case study of a dairy processing facility. Journal of Cleaner Production, 102, 275-284. https://doi.org/10.1016/j.jclepro.2015.04.069

Alinsafi, A., Khemis, M., Pons, M. N., Leclerc, J. P., Yaacoubi, A., Benhammou, A., \& Nejmeddine, A. (2005). Electro-coagulation of reactive textile dyes and textile wastewater. Chemical Engineering and Processing: Process Intensification, 44(4), 461-470. https://doi.org/10.1016/j.cep.2004.06.010

Fukushima, Y., \& Tan, Y. S. (2014). A systematic framework to assess the feasibility and effectiveness of carbohydrate-rich wastewater treatment with bioresource exploitation alternatives in small- and medium-sized enterprises. Journal of Cleaner Production, 74, 172-182. https://doi.org/10.1016/j.jclepro.2014.03.058

Ioannou-Ttofa, L., Michael-Kordatou, I., Fattas, S. C., Eusebio, A., Ribeiro, B., Rusan, M., ... Fatta-Kassinos, D. (2017). Treatment efficiency and economic feasibility of biological oxidation, membrane filtration and separation processes, and advanced oxidation for the purification and valorization of olive mill wastewater. Water Research, 114, 1-13. https://doi.org/10.1016/j.watres.2017.02.020

Kobya, M., Can, O. T., \& Bayramoglu, M. (2003). Treatment of textile wastewaters by electrocoagulation using iron and aluminum electrodes. Journal of Hazardous Materials, 100(1-3), 163-178. https://doi.org/10.1016/S0304-3894(03)00102-X

Ngatin, Agustinus; Sarungu, Yunus; Gozali, M. (2010). Pengaruh Pasangan Elektroda Terhadap Proses Elektrokoagulasi Pada Pengolahan Air Buangan Industri Tekstil. Jurnal Refrigerasi, Tata Udara Dan Energi, Vol.4, No, 421.

Ross, P. . (1996). Taguchi Techniques for Quality Engineering. New York: Mc Graw-Hill Companies Inc.

Siringo, E; Kusrijadi, A; Sunarya, Y. (2013). Penggunaan Metode Elektrokoagulasi Pada Pengolahan Limbah Industri Penyamakan Kulit Menggunakan Aluminium Sebagai Sacrificial Electrode. Jurnal Sains Dan Teknologi Kimia, Volume 4., 96-107.

Sulaksono, A., Effendi, H., \& Kurniawan, B. (2015). Kajian Beban Pencemaran Limbah Cair Industri Kecil Menengah (Ikm) Batik Klaster Trusmi Kabupaten Cirebon. 2015, 5(1), 17 24. https://doi.org/10.19081/jpsl.2015.5.1.17. 